\title{
Actions of L-citrulline on gastric mucus secretion and gastric mucous cell counts in albino rats
}

\author{
${ }^{1}$ Oluwole, F.S., ${ }^{1,2}$ Adebayo-Gege,G.I, and ${ }^{1}$ Folarin,S.A \\ ${ }^{I}$ Department of Physiology, College of medicine, University of Ibadan, Ibadan, Nigeria \\ ${ }^{2}$ Department of Physiology, Bingham University, auta-baleefi,Nasarawa,Nigeria
}

\begin{abstract}
Oral L-citrulline is efficiently converted to L-arginine, the precursor for endothelial nitric oxide (NO) synthesis.Nitric oxide NO enhances gastric mucus production. This study investigates the role of nitric oxide as up regulator of mucus secretion and mucous cell count in the stomach. Sixty Adult male albino rats, weighing between 180-210 g were used for the experiment. They were divided into two study groups, (gastric mисиs secretion study group, gastric mисиs cell count study group), of thirty rats per group and each group was further subdivided into five groups with six (n=6) rats in each group. Group (I) served as control. Group (II) was treated with L-Citrulline $(600 \mathrm{mg} / \mathrm{kg}$ ) for five days. Group (III) received L-Citrulline $(900 \mathrm{mg} / \mathrm{kg})$ for five days. Group (IV) received L-Arginine (200mg/kg) and group (V) was treated with misoprostol (100 $\mathrm{\mu g} / \mathrm{kg})$. Gastric mucus wall content was determined by Alcian blue method and the rate of secretion was determined by the quantity of Alcian blue extract per gram wet stomach $(\mathrm{mg} / \mathrm{g})$. The tissues were fixed in $10 \%$ formalin and embedded in Paraffin wax, then sectioned with microtome at 4microns. The mucus cell count was counted using calibrated microscope in five randomly selected areas of the gastric mucosal tissue on each slide. The results show that in the first study group, L-citrulline increases the rate of gastric mисиs secretion from $7.4 \pm 1.58 \mathrm{mg} / \mathrm{g}$ tissue in the control to $12.7 \pm 5.05 \mathrm{mg} / \mathrm{g}$ tissue in the $600 \mathrm{mg} / \mathrm{kg}$ treated in group 2, while group 4 treated with Larginine the secretion is about $11.30 \pm 2.64 \mathrm{mg} / \mathrm{g}$ per tissue while in the second study group, the mucus cell count in the control is $14.50 \pm 2.56$ cells $/ \mathrm{mm}^{2}$ and it decreases to $10.75 \pm 1.80$ and $14.20 \pm 3.80 \mathrm{cells} / \mathrm{mm}^{2}$ in $600 \mathrm{mg} / \mathrm{kg}$ and $900 \mathrm{mg} / \mathrm{kg}$ l-citrulline treated group while it increases to $15.60 \pm 2.27 \mathrm{cells} / \mathrm{mm}^{2}$ and17.96 $\pm 2.73 \mathrm{cells} / \mathrm{mm}^{2}$ in the L-arginine and misoprotol treated group. It is therefore concluded that L-citrulline increases gastric mucus secretion which could be as a result of up-regulation of endothelial Nitric oxide via the citrulline-NO cycle.
\end{abstract}

Key words: L-citrulline,gastric mucus, gastric mucous cells,L-arginine,nitric oxide

\section{Introduction}

$\mathrm{L}$-arginine is the substrate for endothelial nitric oxide $(\mathrm{NO})$ production, which is protective factor that maintains the gastric mucosa intergrity by increasing the mucosal barrier, mucus secretion ,blood flow, cell regeneration. (Singha et al., 2008, Taddei et al., 2003).From previous studies, L-arginine can be synthesized from L-citrulline via the citrulline-NO cycle resulting in increased endothelial NO production(Flam et al., 2007). Oral L-citrulline (6 g/day) provides greater circulating L-arginine levels than a similar dose of L-arginine due to an efficient conversion of L-citrulline to L-arginine (Schwedhelm et al.,2008, Waugh et al.,2001).Similarly, L-citrulline from watermelon is efficiently converted to L-arginine (Collins et al.,2007). Peptic ulcers are open sores in mucous lining of the stomach and duodenum. The annual mortality rate due to peptic ulcer is not low and deaths are largely due its complications such as hemorrhage and perforation (Isemberg and Soll, 1996). The risk of developing an ulcer depends upon an imbalance between aggressive factors such as acid and pepsin, and defensive mechanisms like gastric mucous, high mucosal blood flow and high mucosal. The pathogenesis of peptic ulcer is far from clear and so also the mechanism of anti-ulcer drugs (Akimoto et al, 1998).There are many factors that is involved in gastric and duodenal ulcer pathology such as stress, smoking, nutritional deficiencies, alcohol ingestion and non-steroidal anti-inflammatory drugs (Basil and Howard,1995). For instance, the use of NSAID stimulates $\mathrm{HCl}$ secretion and cause weakness of mucous gel layer which act as barrier by decreasing mucin production and increasing the secretion of bicarbonate from gastric and duodenal mucosa (Huang et al, 2002).These studies suggest that gastric mucus content, increase in gastric mucous cells count could contribute significantly to maintaining normal gastric integrity. In this study, actions of L-citrulline on gastric mucous secretion and mucus cell count is evaluated.

\section{Drug Preparation}

\section{Method}

L-citrulline (L-Cit) was dissolved in distilled water. It was prepared freshly each time and given at different doses $(600$, and $900 \mathrm{mg} / \mathrm{kg}$ ) by gavage. L-arginine was also dissolved in distilled water and given at $200 \mathrm{mg} / \mathrm{kg}$ intraperitoneally .Misoprostol was also dissolved in distilled water and given at $100 \mu \mathrm{g} / \mathrm{kg}$ by 
intragastric gavage .Drugs were administered 2 hours before the animals were sacrificed and their stomachs harvested.

\section{Animals}

The study protocol was approved by the Institutional Animal Ethical Committee, University of Ibadan. Male Wistar rats weighing 180-210 g were procured from the institutional animal house and were housed in groups of 5 in each study group. The animals were acclimatized for a duration of 7 days at $25 \pm 1$ oC and 12:12 h light-dark cycle with free access to food and water. The animals were deprived of food $24 \mathrm{~h}$ before the study and transferred to metabolic cages so as to avoid coprophagy.

GroupI: serves as control and were given $1 \mathrm{ml}$ of normal saline.

GroupII:weretreated with L-Citrulline $(600 \mathrm{mg} / \mathrm{kg}$ ) for five days GroupIII: were treated with L-Citrulline $(900 \mathrm{mg} / \mathrm{kg})$ for five days GroupIV: were treated with L-Arginine $(200 \mathrm{mg} / \mathrm{kg})$

GroupV:were treated with misoprostol $(100 \mu \mathrm{g} / \mathrm{kg})$

\section{Measurement of mucus production}

Gastric mucus production was measured in the rats that were treated with different drugs. The gastric mucosa of each rat was gently scraped using a glass slide. The gastric barrier mucous was estimated by the method of Corne et al (1974).Briefly, the excised stomachs from the rats were soaked for 2 hours in $0.1 \%$ Alcian blue dissolved in buffer solution containing 0.1M sucrose and 0.05M Sodium acetate (pH adjusted to 5.8 with hydrochloric acid). After washing the stomach twice in $0.25 \mathrm{M}$ sucrose (15 and $45 \mathrm{~min}$ ), the dye complexed with mucous was eluted by immersion in $10 \mathrm{ml}$ aliquots of $0.5 \mathrm{M} \mathrm{MgCl} 2$ for 2 hours. The resulting blue solution was shaken with equal volumes of diethyl ether and the optical density of the aqueous phase measured at 580nM using a spectrophotometer. The quantity of Alcian blue extract per gram wet stomach (mg/g) was then calculated from a standard curve.

\section{Gastric MucusSecretion(mg/g)= Weight Of stomach/ Weight of Wet Stomach $(\mathrm{g})$ Histological studies}

The tissues were fixed in $10 \%$ formalin. They were then processed in Automatic tissue processor. The tissues were then embedded in Paraffin wax. They were thereafter sectioned with microtome at 4 microns. The sections were then floated on frosted end slide. The slides were fixed on hotplate for about thirty minutes. The sections were then stained by Periodic Acid Schiff.

\section{Mucus Cell count.}

The mucus cell count was counted using calibrated microscope in five randomly selected areas of the gastric mucosal tissue on each slide. Each selected area assessed five cubic boxes (Li et al,2002).The microscope was calibrated by inserting into its eyepiece a transparent nylon with drawn squares $(2 \mathrm{~mm}$ by $2 \mathrm{~mm}$ each) on its surface. The squares were faintly drawn such that the gastric mucus cell could be seen properly. The nylon was cut out in such a way that it directly fixes into the round hole of the microscope eyepiece

\section{Statistical analysis}

All the values were tabulated and presented in the tables and were expressed as mean \pm standard error mean(SEM) of six animals. Significant difference among the means were calculated at the level of ${ }^{*} \mathrm{P}<0.05$ when compared with controls. The statistical significance was calculated using students ' $t$ ' test

\section{Result}

L- citrulline shows a dose dependent up regulation of mucous secretion and mucus cells. Maximum production of mucous was seen in the $600 \mathrm{mg} / \mathrm{kg}$ l-citrulline treated group. Even though L-citrulline produced a significant production of mucous secretion in the higher dose treated groups (600 and $900 \mathrm{mg} / \mathrm{kg}$ body weight), all other test groups also produce significant increase in gastric mucous secretion as compared to the control. Lcitrulline in a dose of $600 \mathrm{mg} / \mathrm{kg}$ body weight was more efficacious than the dose of $900 \mathrm{mg} / \mathrm{kg}$ body weight, Larginine $(200 \mathrm{mg} / \mathrm{kg}$ body weight) and misoprostol $(100 \mu \mathrm{g} / \mathrm{kg}), \mathrm{p}<0.05$. L-Citrulline also showed a significant increase in mucus cell count in the stomach tissue. The mucus cell count was significantly high in misoprostol treated(standard group )as compared with the control,L-citrulline ,L-arginine treated group, $\mathrm{p}<0.05$ as shown table 1 and 2 
Table 1: Analysis of L-Citrulline activity on mucous secretion in the stomach of albino rats Study model 1

\begin{tabular}{|l|l|c|c|}
\hline Grouping & Treatments & No of animals & $\begin{array}{c}\text { gastric mucus } \\
\text { secretion mg/g tissue }\end{array}$ \\
\hline I & Control & 5 & $7.4 \pm 1.58^{*}$ \\
\hline II & $\begin{array}{l}\text { l-citrulline } \\
600 \mathrm{mg} / \mathrm{kg}\end{array}$ & 5 & $12.7 \pm 5.05^{* *}$ \\
\hline III & $\begin{array}{l}1-\text { citrulline } \\
900 \mathrm{mg} / \mathrm{kg}\end{array}$ & 5 & $10.11 \pm 1.83^{* *}$ \\
\hline IV & $\begin{array}{l}1-\text { arginine } \\
200 \mathrm{mg} / \mathrm{kg}\end{array}$ & 5 & $11.30 \pm 2.64 * *$ \\
V & $\begin{array}{l}\text { Misoprostol } \\
100 \mathrm{ug} / \mathrm{kg}\end{array}$ & 5 & $8.71 \pm 2.0^{*}$ \\
\hline
\end{tabular}

All values are expressed as mean \pm SEM, $* \mathrm{P}<0.05$,

$* *=$ highly significant compared with the control,

*= level of significance is not very high compared with control

Table 2: Analysis L-Citrulline activity on mucous secretion in the stomach of albino rats Study model 2

\begin{tabular}{|l|c|c|c|}
\hline Grouping & Treatments & No of animals & $\begin{array}{l}\text { Gastric } \\
\text { counts(cells/mm2 } \\
14.50 \pm 2.56^{* * *}\end{array}$ \\
\hline II & Control & 5 & $10.75 \pm 1.80^{*}$ \\
\hline III & $\begin{array}{l}1-\text { Citrulline } \\
600 \mathrm{mg} / \mathrm{kg}\end{array}$ & 5 & $14.20 \pm 3.80^{* * *}$ \\
\hline IV & $\begin{array}{l}\text { 1-citrulline } \\
900 \mathrm{mg} / \mathrm{kg}\end{array}$ & 5 & $15.60 \pm 2.27^{* * *}$ \\
\hline V & $\begin{array}{l}1-\text { arginine } \\
200 \mathrm{mg} / \mathrm{kg}\end{array}$ & 5 & $17.96 \pm 2.73^{* * *}$ \\
\hline
\end{tabular}

All values are expressed as mean \pm SEM, $* * * \mathrm{P}<0.05,{ }^{*} \mathrm{p}>0.05$

$* * *=$ highly significant compared with the control,

**= have the same level of significance as the control group,

$*=$ level of significance is not very high compared with control

\section{Discussion}

This present experiment studied the effect of L- citruilline on the gastric mucous content rats and the mucous cell count in albino rats and observed that L-citrulline increases the rate of mucus secretion at dose of $600 \mathrm{mg} / \mathrm{kg}-900 \mathrm{mg} / \mathrm{kg}$ of L-citrulline when administered orally. The microscopic observation also shows that Lcitrulline is also effective in up regulation of mucus cell count and not directly related to rate of mucus secretion. At the dose of $600 \mathrm{mg} / \mathrm{kg}$ of L-citrulline, there is higher secretion of mucous, compared with the dose of $900 \mathrm{mg} / \mathrm{kg}$, $* * * \mathrm{p}<0.05$ and the mucus cell count was not significantly high compared with the $900 \mathrm{mg} / \mathrm{kg}$ treated, control and the other tests group. This suggests at a high dose of L-citrulline, its effective in boosting secretion will be affected by increase in the number of mucus cell counts. From previous report, the gastric wall mucus content has been found to play important role in the protection of gastric barriers plays a critical role in the protection of gastric barriers (Gou et al.,2011,Brown et al. 1992). Any decrease in gastric mucus renders the mucosa susceptible to injuries induced by aggressive factors such as acid and pepsin (Nair et al.,2010). Also, studies have shown a protective effect of gastric mucus against oxygen radicals (Cross et al., 1984). Recently, reports indicated that impaired gastric mucus synthesis and secretion occur through a decrease in gastric mucosal cNOS activity in rats subjected to Ishemic Reperfusion injury (Kim and Hwan ,2001; Ohta and Nishida, 2001). L-citrulline, is a non-essential amino acid in mammals, is closely related to biosynthesis of Larginine. It can be readily converted to L-arginine, in the kidney, vascular endothelium and other tissues, thus raising its plasma and tissue levels.(Solomonson et al.,2003).From this study, it was found that L-arginine 
increases the mucus secretion to $11.30 \pm 2.64 * * \mathrm{mg} /$ tissue from $7.4 \pm 1.58 *$ in the control as shown in Table 1, which supports the report by Liu et al.,2008 and Nishida et al.,1997). As an indirect precursor of L-arginine, Lcitrulline has a cardioprotective effect, Previous studies have observed reduction in brachial BP after oral L-arginine supplementation in adults with high BP and concurrent chronic diseases (Palloshi et al., 2004). Oral L-citrulline and watermelon supplementation has been found to reduce peripheral BP and improve endothelium-dependent vasodilation in hypertensive and diabetic rats (Wu et al.,2007, Koeners et al.,2007,). Watermelon supplementation, rich in natural Lcitrulline reduced BP and improve arterial function in adults with high BP, in middle-aged individuals with prehypertension(Figueroa et al.,2010).In the misoprotol $(100 \mu / \mathrm{kg})$,the mucus wall content was $8.71 \pm 2.0^{*}$ which is not as high as in the group treated with $600 \mathrm{mg} / \mathrm{kg}$ and $900 \mathrm{mg} / \mathrm{kg}$ of L-citrulline which indicates that is not as effective as the Lcitrulline. Misoprotol increase the no of cells per $\mathrm{mm}^{3}$ compared with the other groups. This indicates that misoprostol raised the rates of gastric epithelial cell proliferation and this resultant increase in surface mucous cell population could increase the stomach's ability to withstand damage. Therefore, it shows that misoprostol cause hyperplastic response in the gastric mucosa which results in a significantly increased gland cell population, with increase in the mucous and bicarbonate secreting surface. This can also be seen in other groups treated with $900 \mathrm{mg} / \mathrm{kg} \mathrm{L}$-citrulline, L-arginine and the control group and not very significant in $600 \mathrm{mg} / \mathrm{kg} \mathrm{L}$ citrulline treated as shown in the table 2. From the previous studies by Goodlad et al., 1989, that misoprostol effectively elicits a hyperplastic response in the gastric mucosa resulting in a significantly increased gland cell population, with most of the increase occurring in the mucous and bicarbonatc secreting mucous cell surface. The hyperplasia was the result of increased number of mitotic and DNA synthesizing cells in each gastric gland, which resulted in a significant increase in the gland cell production rate, gland per day. In conclusion, Lcitrulline is very effective in increasing the rate of mucous secretion and mucous cell which could be as a result of up-regulation of endothelial Nitric oxide via the citrulline-NO cycle.

\section{References}

[1] Singha S, Khajuriaa A, Tanejab SC, Khajuriab RK, Singha S, Qazia GNThe gastric ulcer protective effect of boswellic acids, a leukotriene inhibitor from Boswellia serrata, in rats. Phytomedicine,2008,15(6-7): 408-415

[2] Taddei S, Ghiadoni L, Virdis A, Versari D, Salvetti A. Mechanisms of endothelial dysfunction: clinical significance and preventive non-pharmacologicaltherapeutic strategies. Curr Pharm Des 2003; 9:2385-2402.

[3] Flam BR, Eichler DC, Solomonson LP. Endothelial nitric oxide production is tightly coupled to the citrulline-NO cycle. Nitric Oxide 2007; 17:115-121.3

[4] Schwedhelm E, Maas R, Freese R, Jung D, Lukacs Z, Jambrecina A, Spickler W,Schulze F, Böger RH Pharmacokinetic and pharmacodynamic properties of oral L-citrulline and L-arginine: impact on nitric oxide metabolism. Br J Clin Pharmacol; 2008, 65:51-59.

[5] Waugh WH, Daeschner CW, Files BA, McConnell ME, Strandjord SE.: Oral citrulline as arginine precursor may be beneficial in sickle cell disease: early phasetwo results. J Natl Med Assoc; 2001,93:363-371

[6] Collins JK, Wu G, Perkins-Veazie P, Spears K, Claypool PL, Baker RA, Clevidence BA Watermelon consumption increases plasma arginine concentrations in adults. Nutrition 2007; 23:261-266.

[7] Isemberg, J.I. and A.H. Soll. Epidemiology,Clinical Manifestation and Diagnosis of Peptic Ulcer.In Cesil Textbook of Medicine, Bonnet, J.C. and F.P.Flum (Edn.). , 1996, Vol. 2, 20th Edn., W.B. Pulb. SounderCompany, USA, pp: 664

[8] Akimoto, M., H. Hashimoto, M. Shigemoto and I.Yakoyama,. Relationship between recurrence ofgastric ulcer and the microcircu lation. J.Cardiovascul. Pharmacol., 1998,31(1):5507.

[9] Basil MD, Howard MS :Clinical Gastroenterology. 4th Ed. NewYork: Mc-Graw- Hill. 1995, pp. $113-161$.

[10] Huang, J.Q., S. Scidher and R.H. Hunt, Role of Helicobacter pylori infection and non steroidal antiinflammatory drugs in peptic ulcer. Ameta-Analysis.Lancet, 2002.,539 (9300): 14-22.

[11] L. Gou, L. Zhang, C. Yin, G. Jia, X. Yin, X. Zhuang,X. Xu, and Y. Liu : Protective effect of L-citrulline against acute gastric mucosal lesions induced by ischemia-reperfusion in rats. Can.J. Physiol. Pharmacol., 2011, 89: 317-327

[12] Brown, J. F., Tepperman, B. L., Hanson, P. J., Whittle, B. J. R. \& Moncada, S. Differential distribution of nitric oxide synthasebetween cell fractions isolated from the rat gastric mucosa.Biochemical and Biophysical Research Communications (1992).,184,680-685

[13] Vinod Nair, Albina Arjuman, H.N. Gopalakrishna, P. Dorababu, Mirshad P.V., Divya Bhargavan and Dipsanker Chatterji: Evaluation of the anti-ulcer activity of NR-ANX-C (a polyherbal formulation) in aspirin \& pyloric ligature induced gastric ulcers in albino rats Indian J Med Res:2010, 132, pp 218-223

[14] Cross,C.E., Halliwell, B., and Allen, A. Antioxidant protection: a function of tracheobronchial and gastrointestinalbmucus. Lancet, 1984,323(8390): 1328-1330.

[15] Kim H, Hwan Kim K.: Role of nitric oxide and mucus in ischemia/reperfusion-induced gastric mucosal injury in rats. J.Pharmacology. 2001,62:200-7.

[16] Ohta, Y., and Nishida, K.:. Protective effect of L-arginine against stress-induced gastric mucosal lesions in rats. Its relation to nitric oxide-mediated inhibition of neutrophil infiltration. Pharmacol.Res. 2001, 43(6): 535-541.

[17] Solomonson, L.P., Flam, B.R., Pendleton, L.C., Goodwin, B.L., and Eichler, D.C.. The caveolar nitric oxide synthase/arginine regeneration system for NO production in endothelial cells. J. Exp.Biol. 2003, 206(12): 2083-2087.

[18] Liu, Y.Z., Zhou, Y., Li, D., Wang, L., Hu, G.Y., Peng, J., and Li, Y.J. Reduction of asymmetric dimethylarginine in the protectiveeffects of rutaecarpine on gastric mucosal injury. Can. J. Physiol.Pharmacol. 2008,86(10): 675-681. doi:10.1139/Y08073. PMID:18841172.

[19] Nishida K, Ohta Y, Kobayashi T, Ishiguro I.: Involvement of the xanthine-xanthine oxidase system and neutrophils in the developmentof acute gastric mucosal lesions in rats with water immersion restraint stress. Digestion; 1997, 58: 340-351

[20] Palloshi A, Fragasso G, Piatti P, Monti LD, Setola E, Valsecchi G, Galluccio E,Chierchia SL, Margonato A. Effect of oral Larginine on blood pressure andsymptoms and endothelial function in patients with systemic hypertension,positive exercise tests, and normal coronary arteries. Am J Cardiol; 2004,93:933-935. 
[21] Wu G, Collins JK, Perkins-Veazie P, Siddiq M, Dolan KD, Kelly KA, Heaps CL,Meininger CJ. Dietary supplementation with watermelon pomace juice enhances arginine availability and ameliorates the metabolic syndrome in Zucker diabetic fatty rats. $J$ Nutr; 2007;137:2680-268

22] Koeners MP, van Faassen EE, Wesseling S, de Sain-van der Velden M, Koomans HA,Braam B, Joles JA Maternal supplementation with citrulline increases renalnitric oxide in young spontaneously hypertensive rats and has long-term antihypertensive effects. Hypertension; 2007. ,50:1077-1084

[23] Arturo Figueroa1, Marcos A. Sanchez-Gonzalez1, Penelope M. Perkins-Veazie2 and Bahram H. Arjmandi1: Effects of Watermelon Supplementation on Aortic Blood Pressure and Wave Reflection in Individuals With Prehypertension: A Pilot Study American Journal of Hypertension, 2010, advance o nline publication

[24] R A Goodlad, A J Madgwick, M R Moffatt, S Levin, J L Allen,And N A Wright, , Prostaglandins and the gastric epithelium: effects of misoprostol on gastric epithelial cell proliferation in the dog. Gut 30, 316-321, 1989

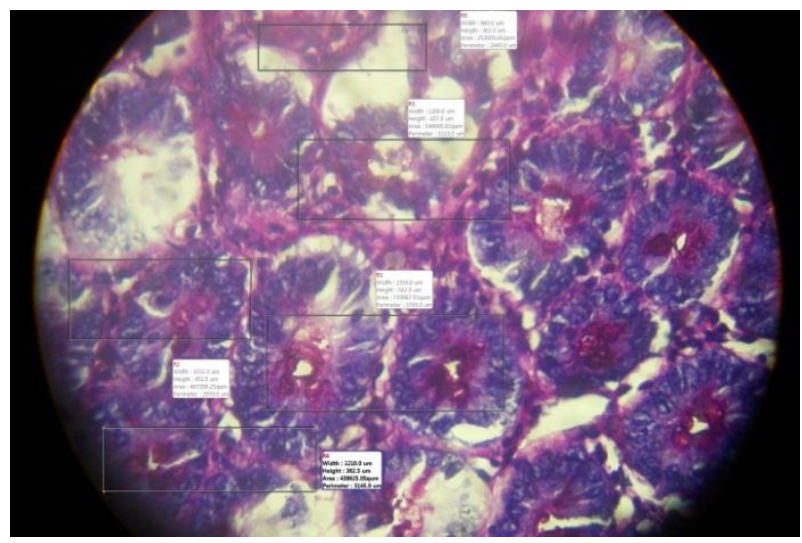

Plate 1: Histological examination of citrulline $(600 \mathrm{mg} / \mathrm{kg})$ on gastric tissue. The mucus cell count was not significant as compared with the control, $p>0.05$. the mucus cell count is $10.75 \pm 1.80 *$

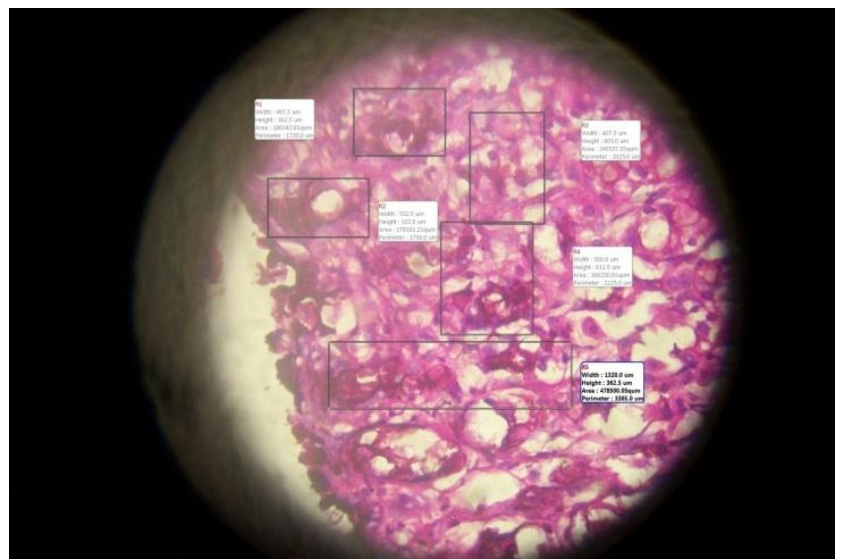

Plate 2: Histological examination of L-arginine $(200 \mathrm{mg} / \mathrm{kg})$ on gastric tissue. The mucus cell count was highly significant as compared with the control, $p<0.05$. the mucus cell count is $15.60 \pm 2.27 * * *$

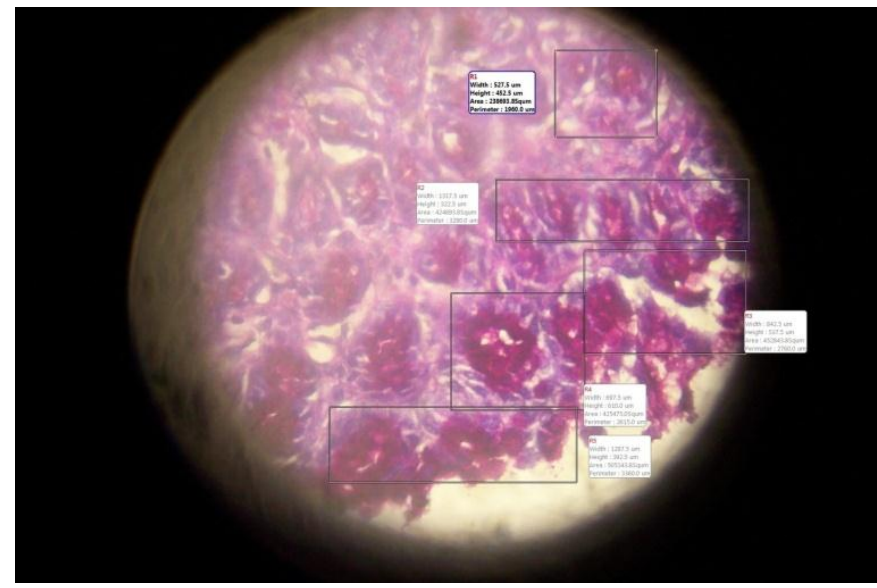

plate 3: Histological examination of gastric tissue of the control group. The mucus cell count is not as significant as in the standard group. 


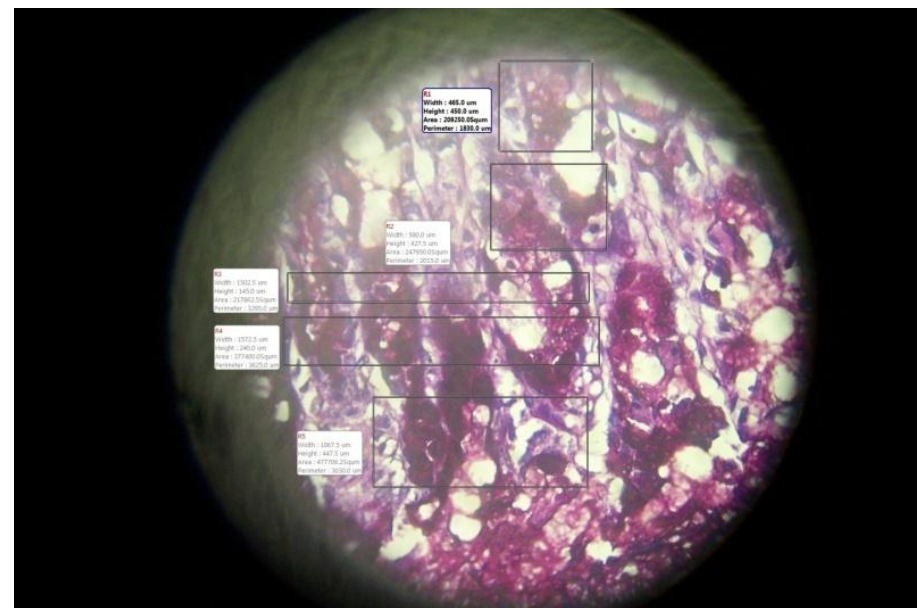

plate 4: Histological examination of Misoprotol $(100 \mu \mathrm{g} / \mathrm{kg})$ on gastric tissue. The mucus cell count was highly significant as compared with the control, $p<0.05$.

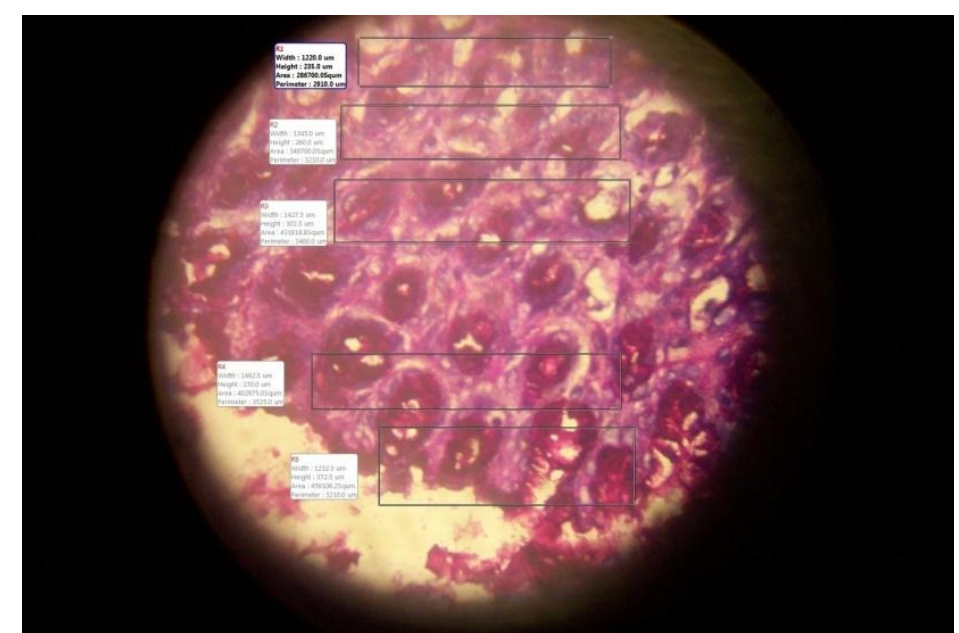

plate 5: Histological examination of L-Citrulline $(900 \mathrm{mg} / \mathrm{kg})$ on gastric tissue. The mucus cell count was not as significant as compared with the control, $p<0.05$ 